\title{
Material Identifier Type Code
}

National Cancer Institute

\section{Source}

National Cancer Institute. Material Identifier Type Code. NCI Thesaurus. Code C93863.

A coded value specifying the kind of material identifier. 